\title{
Histopathology of mitochondrial cytopathy and the Laurence-Moon-Biedl syndrome
}

\author{
PAUL RUNGE,' DAVID CALVER, ${ }^{2}$ JOHN MARSHALL, ${ }^{3}$ AND DAVID TAYLOR' \\ From the 'Department of Ophthalmology, Hospital for Sick Children, Great Ormond Street, ${ }^{2}$ Guy's Hospital,

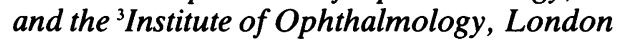

SUMmARY Clinical and histopathological studies of two patients with distinctly different inherited juvenile retinal dystrophies indicate that the ocular defect in mitochondrial cytopathy involves the underlying pigment epithelium, whereas in the Laurence-Moon-Biedl syndrome the photoreceptor cells are primarily affected

Many retinal dystrophies occur in early childhood, but only a few have known metabolic defects. We present the histopathology of two patients, each representing a specific subcategory of retinal dystrophy. The first is associated with the KearnsSayre syndrome (a mitochondrial cytopathy), the second is part of the Laurence-Moon-Biedl syndrome.

The mitochondrial cytopathies (MCs) are progressive disorders affecting many organ systems. The underlying defect appears to be a malfunction within the mitochondria. In skeletal muscle these abnormal mitochondria cluster together giving the appearance of 'ragged red fibres' on light microscopy. When studied by transmission electron microscopy these organelles contain abnormal cristae or crystallinelike inclusion bodies.' Histochemistry is a useful adjunct in demonstrating the abnormal mitochondria, whose appearance represents the result of their inability to meet the cell's energy requirements and does not imply a common aetiology. ${ }^{2}$ It is likely that MCs are a spectrum of disorders with various mitochondrial or paramitochondrial enzymatic defects. The Kearns-Sayre syndrome is a distinct clinical entity within the spectrum of MCs.

In 1958 Kearns and Sayre described the triad of retinitis pigmentosa, external ophthalmoplegia, and heart block. ${ }^{3}$ Affected patients have a great variety of signs and symptoms which include: external ophthalmoplegia $(100 \%)$, retinal pigmentary degeneration $(100 \%)$, ptosis $(100 \%)$, cardiac conduction defects

Correspondence to Mr D S I Taylor, Department of Ophthalmology, Hospital for Sick Children, Great Ormond Street, London WC1N 3JH.
(84\%), muscle weakness $(77 \%)$, cerebellar dysfunction $(69 \%)$, short stature $(63 \%)$, and neurosensory hearing loss $(54 \%))^{47}$ In MCs there is an abnormal elevation of the cerebrospinal fluid protein. Less commonly, hypoplastic anaemia, impaired renal function, diabetes mellitus, raised serum alanine and creatinine kinase (CK), low serum calcium and parathyroid hormone (PTH), and metabolic acidosis have been reported.

The Laurence-Moon-Biedl syndrome also has retinal manifestations. The classic pentad includes retinal dystrophy $(93 \%)$, obesity $(91 \%)$, mental retardation $(87 \%)$, hypogenitalism $(74 \%)$, and polydactyly $(73 \%) .{ }^{9}$ The full spectrum of clinical features is found in only 40 to $45 \%$ of cases, ${ }^{10}$ and many incomplete forms have been described. Variability in gene expression and difficulty in detecting some clinical features (obesity, mild mental retardation, and hypogenitalism) in infancy have made clear characterisation of the syndrome difficult in some cases. Renal and upper urinary tract abnormalities are a feature not included in the classic pentad of this syndrome, but reports suggests that these anomalies are common, ${ }^{11} 12$ and perhaps urological involvement is a characteristic feature of the syndrome." Alternatively, upper genitourinary tract abnormalities are associated with maldevelopment of the lower tract and may be considered to be an extension of the hypogenitalism..$^{13-15}$

\section{Case reports}

\section{CASE I: MITOCHONDRIAL CYTOPATHY}

This girl was born after a 39 weeks normal pregnancy weighing $7 \mathrm{lb} 12 \mathrm{oz}(3515 \mathrm{~g})$. Her parents were 


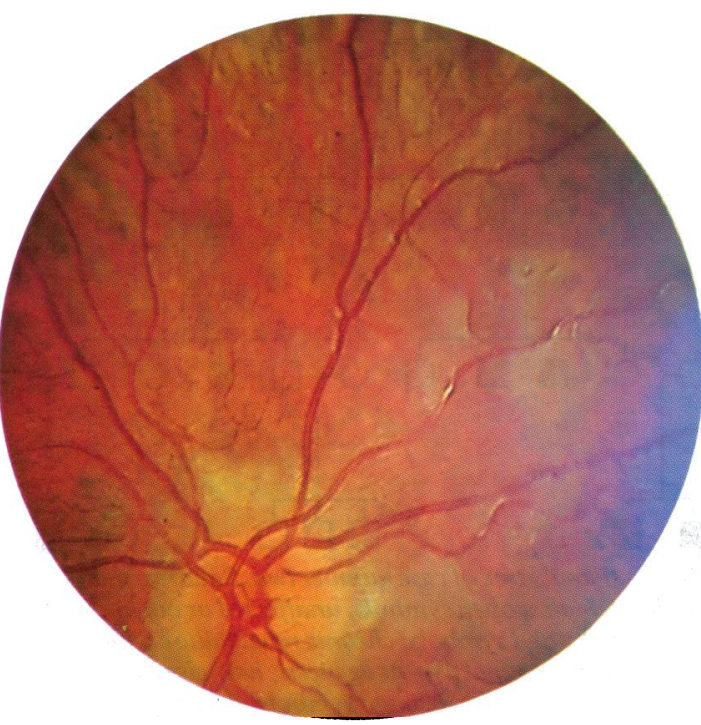

Fig. 1a The ocular fundus in case 1 (Kearns-Sayre syndrome), showing a relatively normal appearing posterior pole.

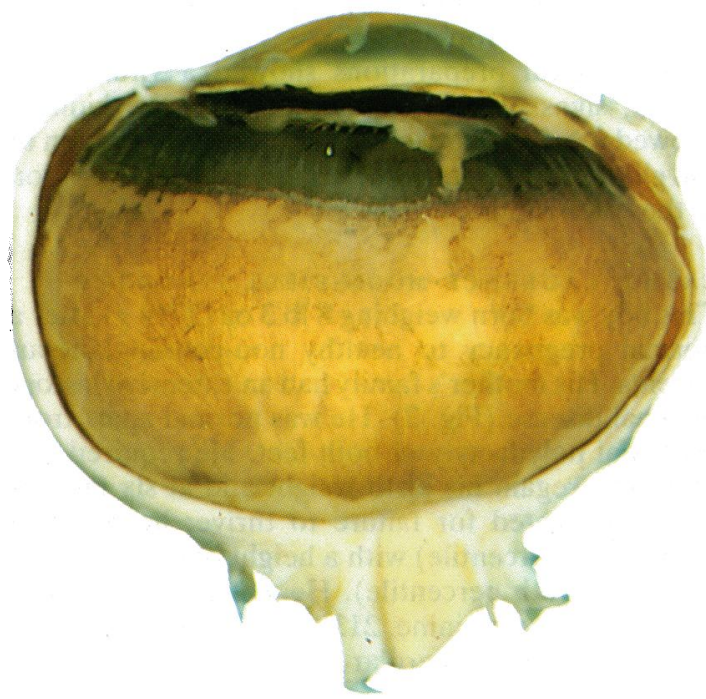

Fig. 1c The hemisected globe in case 1, which clearly shows the discontinuous salt-and-pepper pigmentation.

healthy and not consanguineous. She had two normal siblings, and there was no significant family history. She was healthy until 8 months old, when she was noted to be pale and was found to have prednisolone responsive red cell hypoplasia. From $4 \frac{1}{2}$ years she failed to thrive, with height and weight falling to less than the 3 rd percentile.

Renal failure was diagnosed at $91 / 2$ years and a

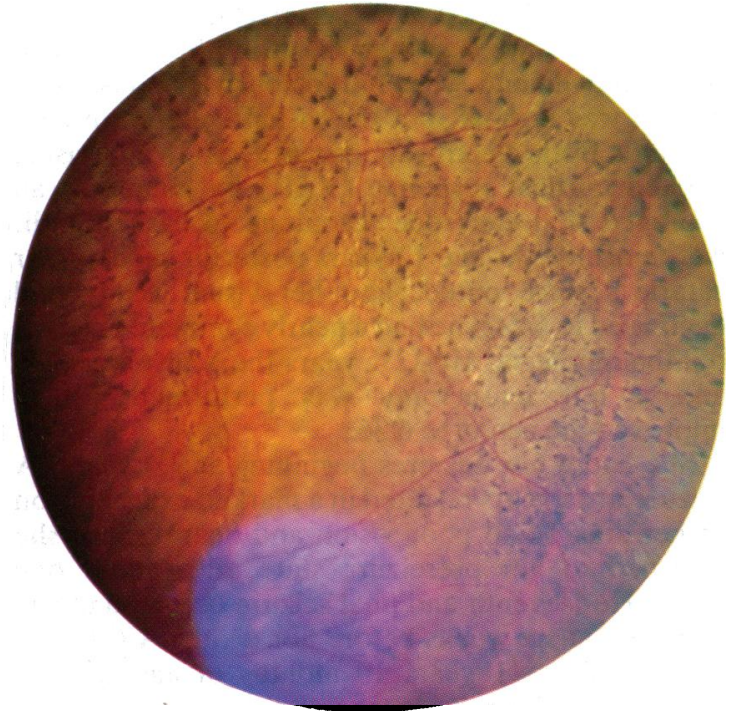

Fig 1b The peripheral fundus in case 1 (Kearns-Sayre syndrome). Note the salt-and-pepper pigmentation. Both fundus photographs were taken at 9 years 3 months of age.

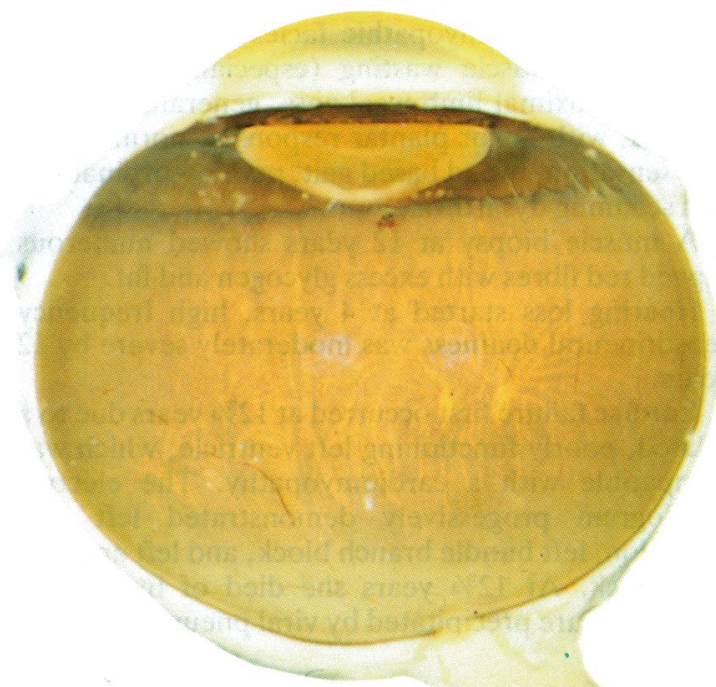

Fig. 1d The hemisected globe in case 2, which appears normal.

renal biopsy performed at $93 / 4$ years was suggestive of juvenile nephronophthisis. Subsequently she required dialysis, and at $11 \frac{1}{2}$ years a renal transplant was performed. Soon afterwards she developed insulin dependent diabetes mellitus possibly related to steroid therapy.

She required spectacles from an early age for hypermetropic astigmatism. A pigmentary retino- 
pathy was first noted at $91 / 2$ years (Figs. 1a and $1 \mathrm{~b}$ ); her visual acuity was then $6 / 9$ in both eyes, extraocular movements were full, colour vision (Ishihara plates) was normal, but the visual fields were constricted. Both electroretinogram (ERG) and visual evoked cortical response (VER) by means of an averaged skin electrode technique to flash stimuli, were normal. At age 12 years posterior subcapsular cataracts were noted, and her visual acuity had decreased to $6 / 24$; she had a nearly complete external ophthalmoplegia. By $12 \frac{1}{2}$ years the acuity was $3 / 36$ and a left lensectomy was performed, which improved the acuity to $6 / 36$.

She had a few seizures beginning at $93 / 4$ years. A seizure at 11 years resulted in a marked exaggeration of her ataxia and poor vision and hearing, but she returned to her preseizure state after about one week. Her seventh and final seizure occurred at age 12 years, at six weeks before her death. A CT scan performed at 11 years 10 months of age showed cerebellar and cerebral atrophy.

From 10 years of age she had a variable ataxia and by $11 \frac{1 / 2}{2}$ years she required support to walk; a generalised myopathy was also then apparent with normal sensory and motor nerve conduction. At 12 years she had a myopathic facies, marked ptosis, generalised muscle wasting (especially the quadriceps), proximal limb weakness, generalised hyporeflexia, with flexor plantar responses, normal tone and sensation, broad based gait, poor co-ordination, and scanning dysarthria.

A muscle biopsy at 12 years showed numerous ragged red fibres with excess glycogen and fat.

Hearing loss started at 4 years, high frequency sensorineural deafness was moderately severe by 12 years.

Cardiac failure first occurred at $123 / 4$ years due to a dilated, poorly functioning left ventricle, which was compatible with a cardiomyopathy. The electrocardiogram progessively demonstrated left axis deviation, left bundle branch block, and left anterior hemiblock. At $123 / 4$ years she died of intractable cardiac failure precipitated by viral pneumonia.

\section{Investigations}

These showed a hypochromic normocytic anaemia, raised cerebrospinal fluid (CSF) protein $(1000 \mathrm{mg} / 1)$; low serum parathormone (PTH) $(50,90$, and 120 $\mathrm{ng} / \mathrm{l})$, and creatine kinase at the upper limit of normal (60 IU/1). Alanine was noted in her urine, and she showed a corrected metabolic acidosis with low calcium and high phosphate.

Necropsy results

She had pneumonitis, and the heart was moderately enlarged and dilated with a pale myocardium. The

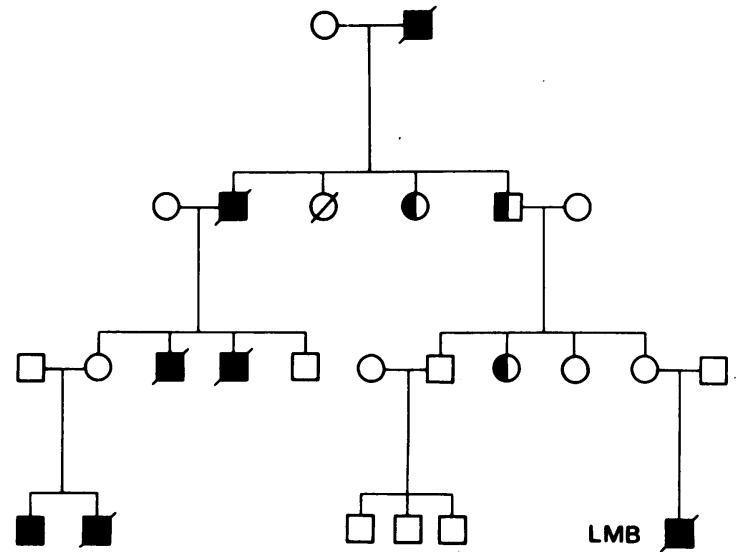

Fig. 2 Family tree of case number two. Squares, males; circles, females; open symbols, unaffected or not known to be affected; solid symbols, chronic renal failure with or without proved renal dys-or agenesis, half-closed symbols, duplex kidneys; slash through symbols, deceased. $\mathrm{LMB}=$ Laurence-Moon-Biedl syndrome .

liver showed fatty changes, and the kidneys were atrophic but otherwise appeared normal. The adrenals were atrophic.

Histological preparations showed a viral pneumonia, signs of cardiomyopathy, and the kidneys showed tubular atrophy with relative preservation of the glomeruli. There was Purkinje cell degeneration in the cerebellum.

CASE 2: LAURENCE-MOON-BIEDL SYNDROME

This boy was born weighing $8 \mathrm{lb} 3 \mathrm{oz}(3714 \mathrm{~g})$ after a normal pregnancy to healthy non-consanguineous parents. His mother's family had an extensive history of renal disease (Fig. 2). He was normal apart from postaxial polydactyly of both feet. He required one month to regain his birth weight and at six months was investigated for failure to thrive; he weighed $6.5 \mathrm{~kg}$ (3rd percentile) with a height of $64.5 \mathrm{~cm}$ (just below the 10th percentile). He was in renal failure with plasma creatinine $213 \mu \mathrm{mol} / \mathrm{l}$ and urea 15.9 $\mathrm{mmol} / \mathrm{l}$, and the glomerular filtration rate (GFR) was $11 \mathrm{ml} / \mathrm{min} / 1.73 \mathrm{~m}$ surface area. The intravenous pyelogram (IVP) and cystogram were normal. The renal ultrasound suggested parenchymal cysts. Over the next $3 \frac{1}{2}$ years his renal function gradually deteriorated, and at nearly 4 years peritoneal dialysis was started. He received a renal transplant, followed by several episodes of graft rejection requiring high doses of methylprednisolone and antilymphocyte globulin, during which time he was hyponatraemic, hypertensive, and had three epileptic seizures. Pneumonia and pancytopenia developed, and death occurred at four years one month. 
At nine months of age clinical assessment showed only a minimal hypermetropic astigmatism, but at 10 months he tended to screw up his eyes in bright light and at 13 months he developed occasional jerky horizontal nystagmus. The left fundus was seen clearly and was ophthalmoscopically normal. At 14 months he had constant, variable-amplitude, highfrequency horizontal nystagmus. An examination under anaesthetic (EUA) at $141 / 2$ months showed both eyes to be hypermetropic ( $+5 \cdot 00 \mathrm{R}$ and $\mathrm{L})$, with normal fundi. The ERG was abnormal, with scotopic responses markedly subnormal. The photopic responses to flicker were reduced in amplitude. By two years he had poor vision, especially at night, and coarse nystagmus. An EUA at $2 \frac{1}{4}$ years showed pale discs, attenuated vessels, exposed choroidal vessels, and scattered hyperpigmentation; the ERG was unrecordable. At 4 years old he had bilateral posterior subcapsular cataracts and grossly dystrophic fundi.

A developmental assessment at 2 years 9 months showed motor development delay to the 2-year level, but language comprehension was normal, and there was marked expressive language delay. Hearing was normal.

From $23 / 4$ years he was clumsy, with mild ataxia of both upper limbs and a broad based gait.

\section{Investigations}

He had a normocytic hypochromic anaemia and the plasma levels of creatinine ranged from 215 to 721 $\mu \mathrm{mol} / \mathrm{l}$ and those of urea from 22 to $47 \mathrm{mmol} / 1$, with a GFR of 11 to $5.8 \mathrm{ml} / \mathrm{min} / 1.73 \mathrm{~m}$ surface area. Bone age was delayed, with renal osteodystrophy, and he was hypocalcaemic and hyperphosphataemic, with an alkaline phosphatase of over $1000 \mathrm{IU} / \mathrm{l}$. Parathyroid hormone levels were up to $2610 \mathrm{ng} / \mathrm{l}$. There was a persistent compensated metabolic acidosis. Electro- and echocardiograms were normal.

\section{Necropsy}

The heart was large, with hypertrophy of the ventricular walls. The kidneys were small, dysplastic, and showed nodularity with numerous cysts. The testes were of normal size, and there was no abnormality of the external genitalia. He had bronchopenumonia.

\section{Histological preparation of ocular tissue}

The time from death to enucleation was several hours in case 1 but less than one hour in case 2. A penetrating incision was made of the ora serrata, and the eyes were fixed in $2.5 \%$ glutaraldehyde buffered in $0.2 \mathrm{M}$ sodium cacodylate, containing $10 \mathrm{mg} / \mathrm{ml}$ calcium chloride, with a final $\mathrm{pH}$ of 7.4. After overnight fixation the eyes were hemisected and macrophotographs were taken of their posterior portions.

Samples were taken from the hemisected globes under a dissecting microscope. The specimens were obtained on a horizontal axis from ora to ora through the macula, and vertically from ora to ora through the optic disc, their location, orientation, and relationship to the other samples being recorded so that they could be determined even after being embedded in plastic. The isolated samples were postfixed for one hour in $1 \%$ osmium tetroxide buffered in $0.1 \mathrm{M}$ sodium cacodylate before being dehydrated in a series of ascending concentrations of ethanol in water, and embedded in Araldite (CY212) via epoxypropane. Sections for light microscopy were cut on glass knives and stained with toluidine blue. Ultrathin sections were cut on diamond knives, mounted on uncoated copper grids, stained with uranyl acetate and lead citrate, and examined with an AEI 801 electron microscope.

One eye from each case was processed for tissue culture. This was successful from case 2 , and studies of pigment epithelial cell behaviour have been undertaken. ${ }^{16-18}$

\section{Results}

Neither globe had a macroscopic bone spicule zone.

In case 1 the fundus was pale, with blotchy and discontinuous pigmentation, most dense at the posterior pole and in the far periphery (Fig. 1c), where the pigment was present in both the pigment epithelium (RPE) and the choroid. In the far periphery there were a number of lesions of variable size and shape in which there was a sharply demarcated loss of RPE cells, which reduced the pigment epithelium to a number of random isthmus-like projections of cells, extending centrally from the ora. 1d).

In case 2 the hemisected globe looked normal (Fig.

\section{CASE I}

\section{Histology}

In case 1 there was diffuse and even cell loss in the neural retina, with sectorial disease in the pigment epithelium.

In the macula (Fig. 3a) and far periphery (Fig. 3b) the surviving RPE cells were compressed apicobasally, with sparse amounts of melanin. In the mid periphery there were small focal areas of isolated pigmented cells (Fig. 3c, d) between which the denuded surface of Bruch's membrane was either directly exposed to the remnants of the interphotoreceptor matrix or recolonised by one or more layers of amelanotic cells (Fig. 4a). In a few areas where 
Fig. 3 Light micrographs of wholemount preparations of retinal pigment epithelial cells from a variety of locations in the KearnsSayre syndrome eye. (a) Macula. (b) Farperiphery. (c), (d) Mid periphery. Note that the cells are highly irregular in shape and vary in size. In the mid periphery, focal areas of cell loss result in lesions with sharply defined borders. Scale $=50 \mu \mathrm{m}$.
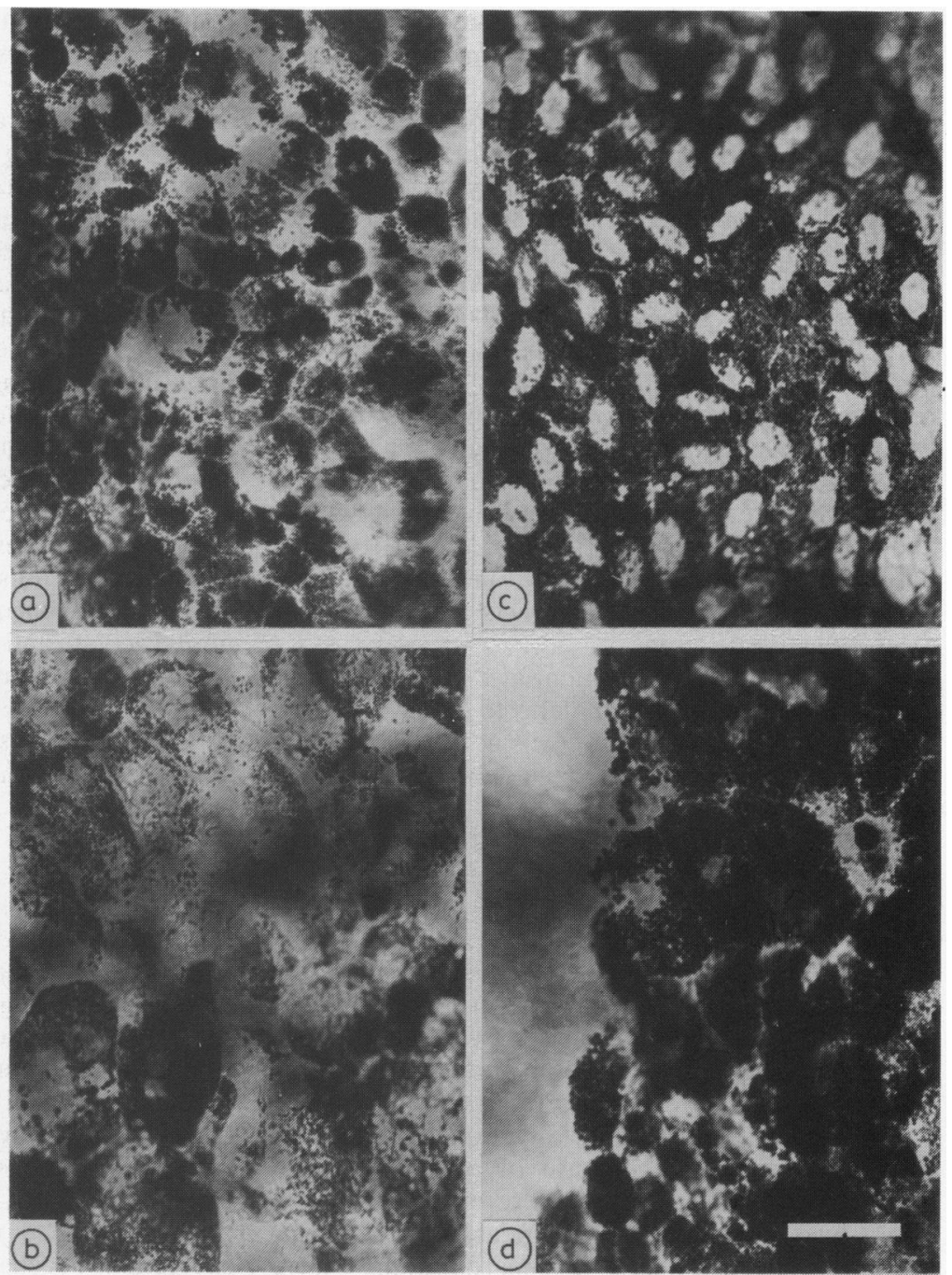

neural retinal cells dipped towards Bruch's membrane, glial proliferation resulted in direct apposition of glial elements with Bruch's membrane. Beneath areas of pigment epithelial cell loss there was also a relative loss of the innermost elements of the choriocapillaris (Fig. 4b). In regions of vessel loss there was no down growth and expansion of columns of Bruch's membrane, as occurs in the elderly, but invasion of fibroblasts and the production of collagen.

All the photoreceptor cells were in a very poor condition (Fig. 5). At the fovea there was a complete loss of photoreceptor cell outer segments, and reduced numbers of cone cell remnants, shown by counting nuclei, which extended into the mid periphery, where both inner and outer segments were absent. In most other conditions, while rod cells degenerate leaving no vestiges, remnants of cone cells may remain for many years, particularly the nucleus and truncated inner segments. Towards the margins of the mid peripheral zone, occasional remnants of inner and outer segments of photoreceptor cells were seen which were always adjacent to islands of pigment epithelial cells; the inner segments were shrunken and stained intensely, while the outer segments were tiny vestiges.

In the space formerly occupied by the interphotoreceptor matrix were numerous spherical lipid droplets of varying diameters and staining properties (Fig. $5 b)$. Some were associated with the apical layer of the pigment epithelium, while in other areas they were 


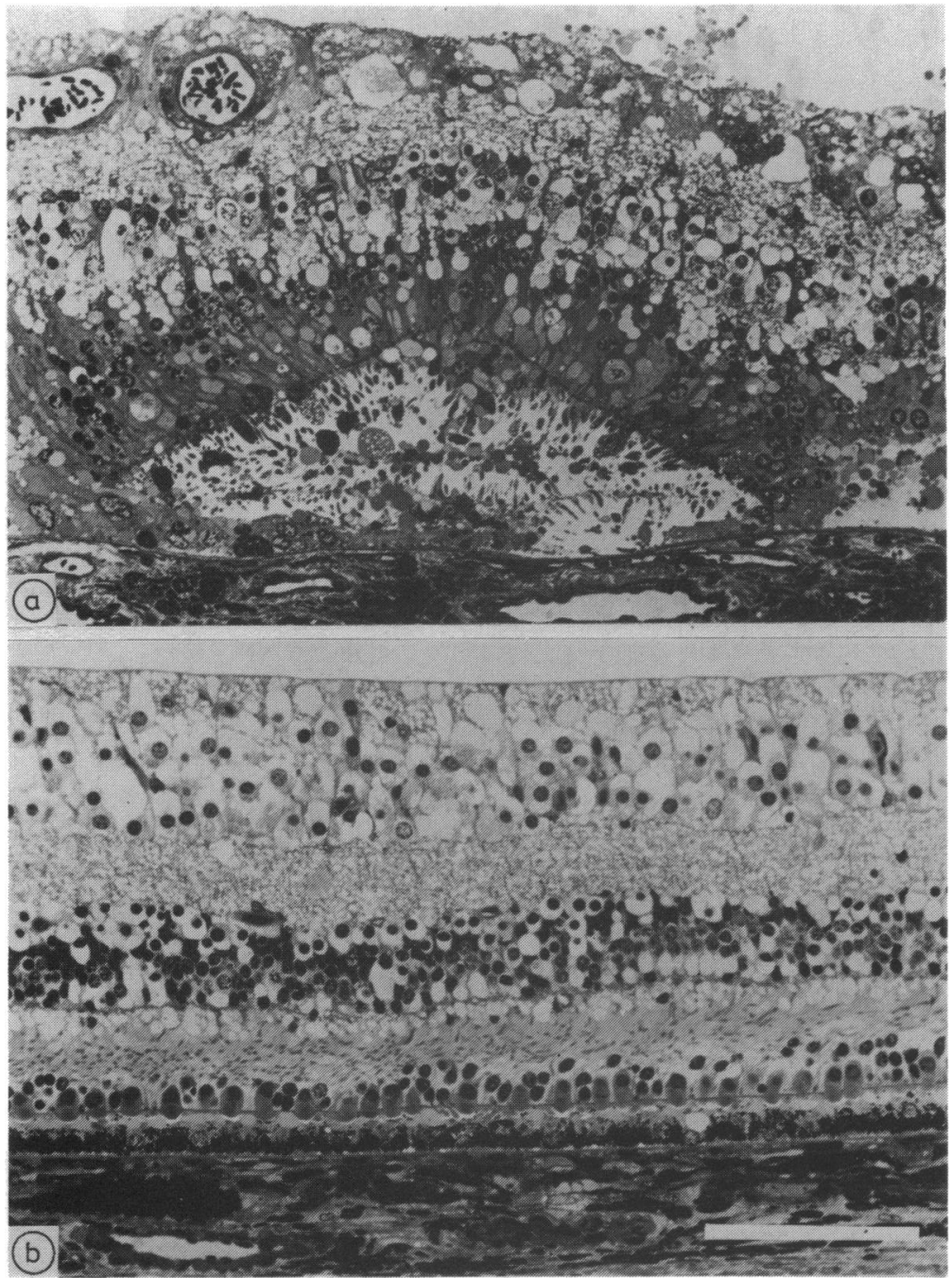

Fig. 4 Light micrographs of retinae of (a) the Kearn-Sayre syndrome and (b) the LaurenceMoon-Biedl case. (a) An area of mid peripheral retina is illustrated with a central region of partially degenerate photoreceptor cells with recognisable inner segments. (b) $A$ representative section of macular retina showing good preservation of the inner retina but a loss of the outer segments of the photoreceptor cells. The 'rounded up' inner segments and nuclei of some affected cones make them particularly prominent. Scale $=100$ $\mu m$.

adjacent to Bruch's membrane. They appeared to represent extracellular accumulations of breakdown products of the outer segment membranes of photoreceptor cells. They were unlike the autolytic debris from long term post-mortem material.

Post-mortem changes in the inner retina showed as areas of vacuolation and oedema in the plexiform layers and pyknosis in the nuclear layers. There was no evidence of trans-synaptic degeneration, and with the exception of pigment epithelium and photoreceptor cells all retinal layers were well preserved, as was the retinal capillary bed.

\section{Ultrastructure}

The post-mortem changes made ultrastructural analysis difficult except on the outer retinal components.

The remaining RPE cells had a primitive appearance, having lost many organelles including melanin granules and lipofuscin (Fig. 6a). Adjacent to photoreceptor cell vestiges there were no phagosomes, and here there were occasional extracellular aggregations of outer segment material associated with the apical membranes of epithelial cells. Commonly there was a reduction in the numbers and complexity of mitochondria in these cells, and unlike in normal cells these few mitochondria were diffuse throughout the cytoplasm. There was a widespread reduction in cell membrane complexity, with loss of apical villi and basal convolutions. Some cells had elaborate arrays 
Fig. 5 Light micrographs of the outer retina and inner choroid in the mid peripheral region of the KearnSayre eye. In both r i...c bare areas of Bruch's membrane are seen, and the choriocapillaris is sparse. (a) Remnants of photoreceptor inner and outer segments (arrowed) were rare and their distribution was not correlated with presence or absence of pigment epithelial cells. (b) An area where the outer components of the photoreceptor cells were absent and subretinal lipid globules (arrowed) and macrophages were apparent in the subretinal space. Scale $=25 \mu \mathrm{m}$.

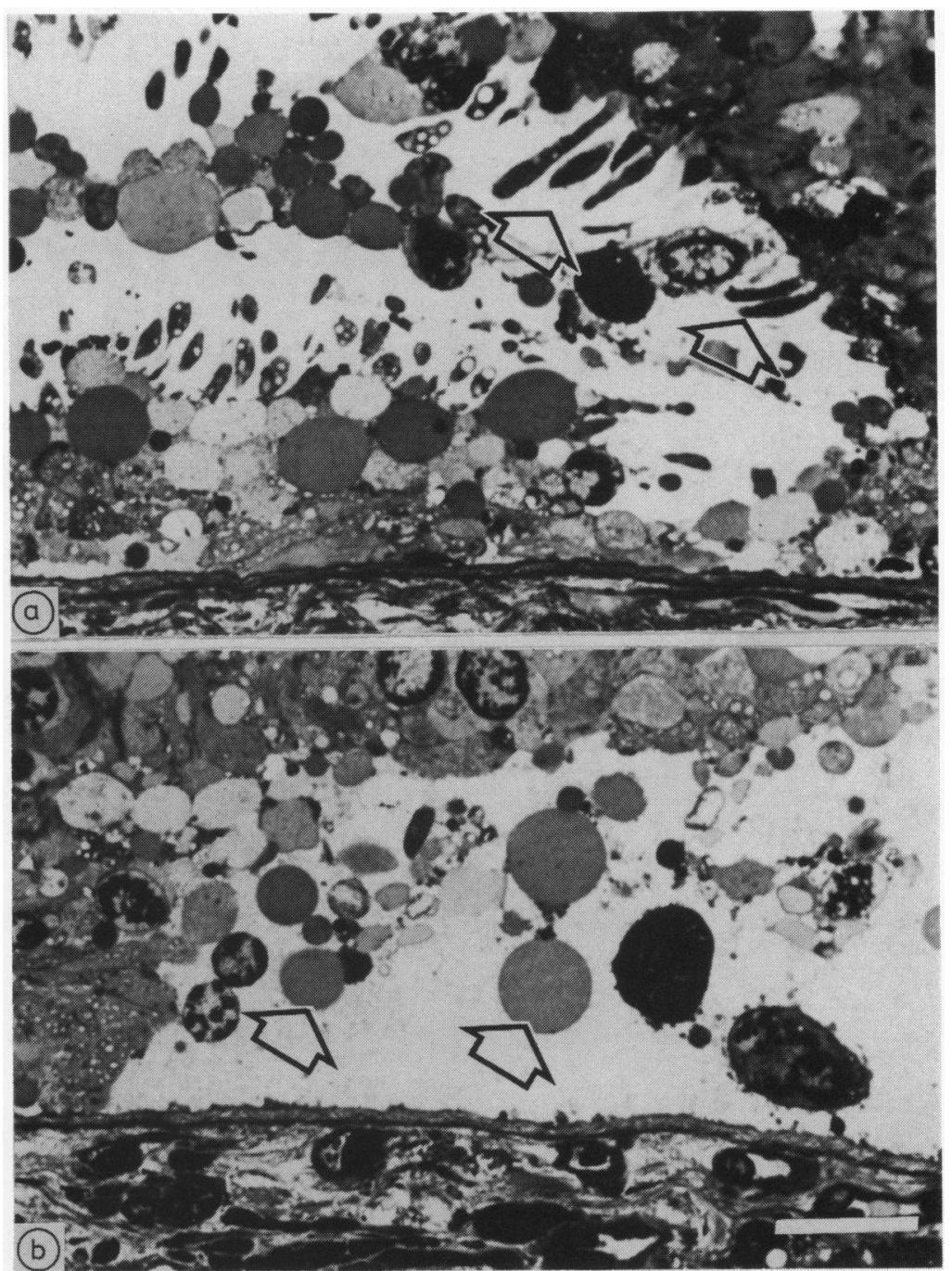

of cytoskeletal elements or filaments, similar to those that developed in tissue cultures. This may be related to the migratory activity of epithelial cells freed from contact inhibition.

Bruch's membrane contained more membranous debris than is normally expected at this age, and its basement membrane component from the pigment epithelium was poorly developed.

Where there were vestiges of inner and outer segments of photoreceptor cells, they were grossly abnormal, and in the inner segments of both rods and cones there were fewer organelles. The remaining mitochondria were shrunken, with densely staining membranes and atypical cristae (Fig. 6b). They did not show the same ultrastructure as the mitochondria of skeletal muscle in mitochondrial cytopathy. The cristae of the photoreceptor cells were swollen and densely packed with a vesicular appearance, without multilayering of cristae or crystal-like inclusions. This is unusual and significant, because the inner segments of photoreceptor cells contain more mitochondria than any other cell. All inner segments contained many autophagic vacuoles of differing morphologies.

The remnants of the rod and cone outer segments were morphologically dissimilar. Most cone outer segments were tiny vestiges, some 2 to $5 \mu \mathrm{m}$ long, with randomised and disorientated vesicular arrays of membranes (Fig. 6c), but a few had degenerated further, and no internal membranes were present and 


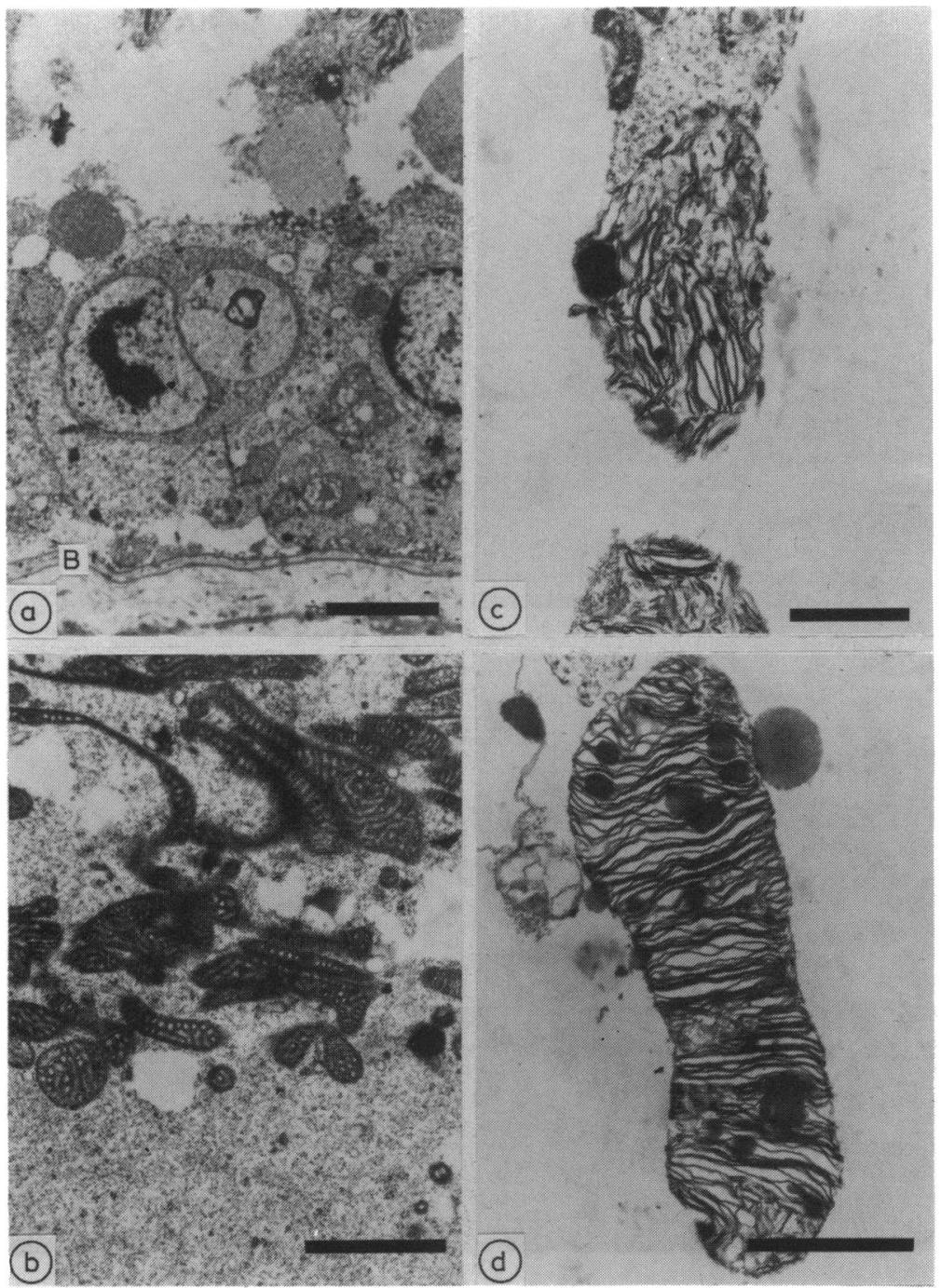

Fig. 6 Representative electron micrographs of a variety of retinal locations in the Kearns-Sayre syndrome eye. (a) An area of Bruch's membrane (B) covered by atypical amelanotic cells which have a very poorly developed basement membrane. The apical membranes of these cells were never complex or seen to exhibit apical villi, and the subretinal space was enlarged. (b) The outer edge of the ellipsoid of a cone remnant showing the presence of slightly shrunken and atypical mitochondria but also demonstrating that they do not have the architecture frequently seen in such organelles in mitochondrial cytopathies. (c) View of the ciliary region of a photoreceptor cell I remnant showing the disorganisation and disorientation of outer segment disc membranes. (d) Shows the peculiar lipid globule inclusions seen in some surviving photoreceptor cell outer segments. Scales are (a) $3 \mu \mathrm{m}$; (b) $2 \mu \mathrm{m}$; (c) $1 \mu \mathrm{m}$; (d) $2 \mu \mathrm{m}$.

the boundary membrane contained a homogeneous granular mass. The remains of rod outer segments were longer, up to $10 \mu \mathrm{m}$, and frequently contained small regions of organised disc membranes. They also showed globular lipid-like inclusions within the membrane stacks of their outer segments and associated with their boundary membranes (Fig. 6d). In areas where rod outer segments were short or absent, there were huge extracellular globules with amorphous or granular staining.

\section{CASE 2}

\section{Histology}

Case 2 showed regional differences in retinal morphology, with the severest changes at the macula, and progressively less marked peripherally (Fig. 4b).

The RPE was relatively normal macroscopically, but on section it had relatively few melanin granules and was full of lipofuscin (Fig. 7). The loss of melanin was most marked at the macula, where there were few intracellular pigment granules. The lipofuscin content in cells was higher than age matched controls, being comparable to those in 20- to 30-yearolds. The general morphology of RPE cells everywhere appeared relatively normal except for a slight increase in apico-basal dimensions; there were no focal lesions or areas of cell loss.

Photoreceptor cell loss was most marked centrally (Fig. 7a), where the foveal cell population was reduced by death and atrophy, with the remaining 
Fig. 7 Light micrographs of (a) the macula and (b) the mid peripheral retina in the LaurenceMoon-Biedl case. (a) Shows a total loss of rod cells and the absence of any outer segment material. Some rounded cone cell remnants are present and the pigment epithelium contains an abnormally high concentration of lipofuscin. (b) Shows remnants of both rod and cone cells with outer segment debris adjacent to the apical membrane of the retinal pigment epithelium. Scales are (a) $20 \mu \mathrm{m}$; (b) $30 \mu \mathrm{m}$.

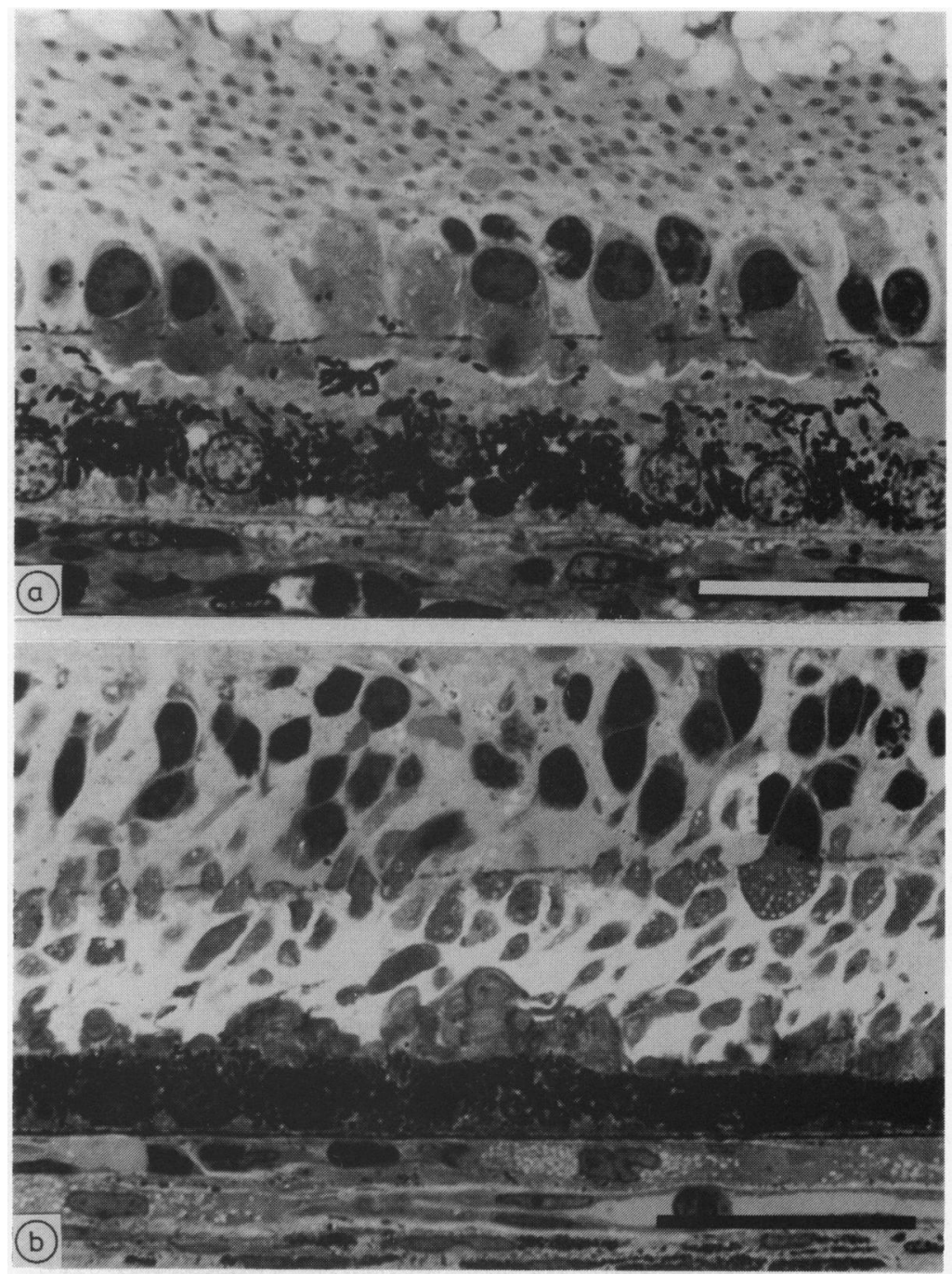

cells losing their outer segments and with their inner segments swollen to the size of those in 60-70-yearold normal persons. The macular outer segments were absent, and rounded inner segments were seen abutted to the pigment epithelium. The cell remnants distorted the outer limiting membrane, making it more prominent, which emphasised the interphotoreceptor matrix. In the mid periphery photoreceptor outer segments of both rods and cones were only half their normal length, and their tips were extremely disorientated at the surface of the pigment epithelium, with an appearance similar to that of the Royal College of Surgeons' rat ${ }^{19}$ (Fig. 7b).

The inner retinal layers were well preserved except at the macula, where there was a reduction in the number of ganglion cells.

\section{Ultrastructure}

The difference in morphology between central and mid peripheral areas was emphasised on electron microscopy.

The central RPE cells contained a variety of densely staining inclusions, including lipofuscin granules, melanolysosomes and melanolipofuscin (Fig. 8a), of various shapes and sizes often associated with lysosomes or microperoxisomes. By reducing available cell volume the waste products reduced the number of active organelles, including mitochondria. Both the apical and basal membranes of the RPE had 


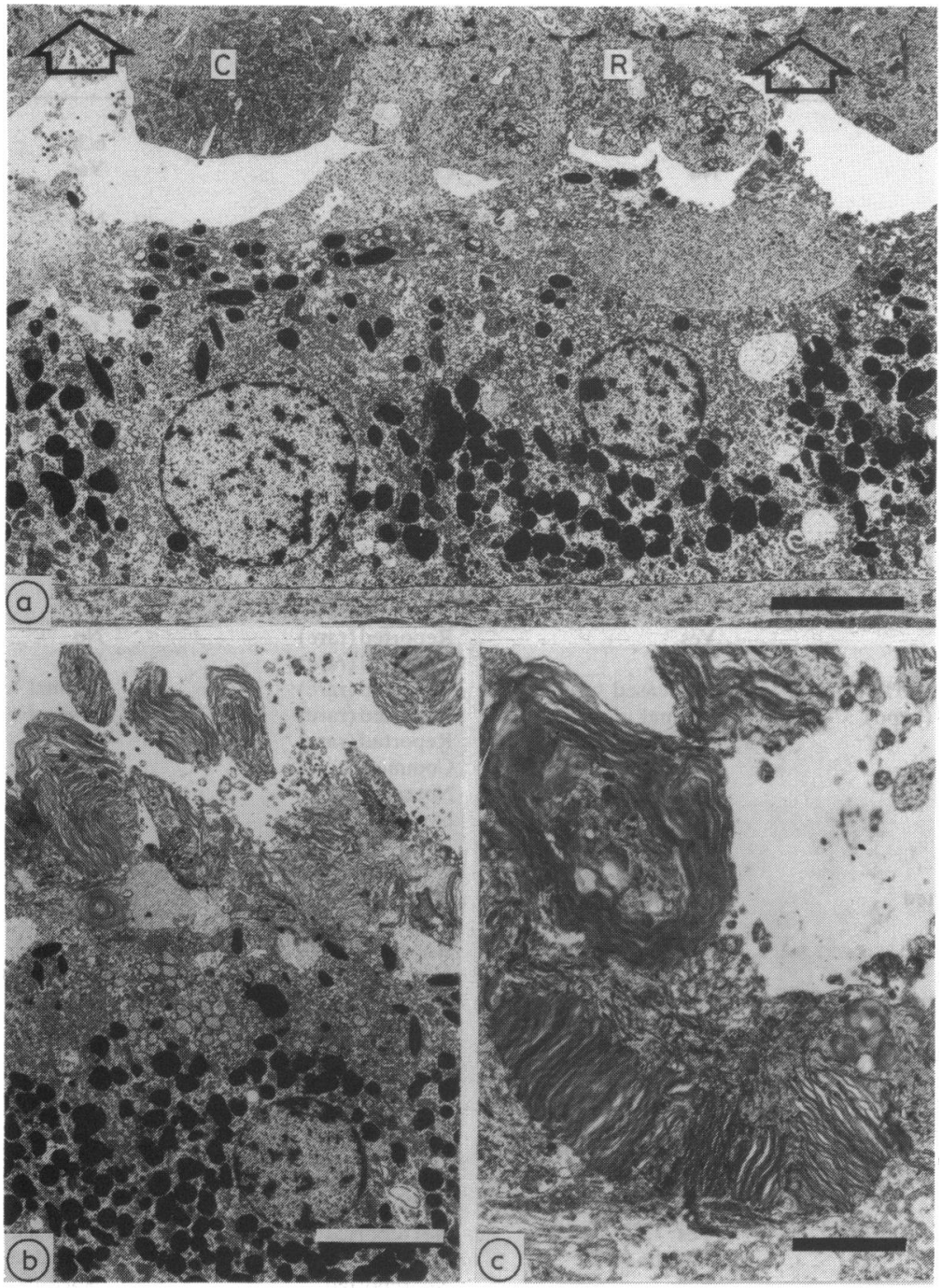

Fig. 8 Electron micrographs of various locations in the retina of the Laurence-Moon-Biedl case. (a) Micrograph to demonstrate the total absence of outer segment material at the macula. The pigment epithelial cells have lost their convoluted basal border and contain abnormally large amounts of lipofuscin. Remnants of both rod $(\mathrm{R})$ and cone $(\mathrm{C})$ inner segments can be seen projecting through the outer limiting membrane (arrowed). (b, c) Micrographs to show the disorganised nature of the extracellular debris of photoreceptor outer segments adjacent to the apical membrane of the retinal pigment epithelium. Scales are (a) and (b) 5 um; (c) $2 \mu \mathrm{m}$.

a simple configuration, with the loss of mircrovilli and basal convolutions.

Apart from a reduced basement membrane in relation to the RPE, Bruch's membrane and the choriocapillaris were normal.

In the mid periphery, where subretinal debris was seen with the light microscope, the RPE cells showed similar abnormalities to their central counterparts, but with more organelles. Their apical membranes lacked microvilli, and there were sheets or whirls of membranes of photoreceptor cell outer segments (Fig. 8b), which were extracellular, and where they were deep to the surface of the RPE they occupied a distended extracellular space between the lateral margins of adjacent cells (Fig. 8c). There were no short-term phagosomes in the cytoplasm of the RPE cells, but huge amounts of lipofuscin, melanoloysosomes, and melanolipofuscin were present, indicating recent phagocytic activity.

The neuroretinal-RPE interface varied throughout the retina because of variable loss of photoreceptor cells. Centrally, 'fat' vestigial cone inner segments were either opposed to the apical surface of the RPE, or were separated from it by tiny deposits of interphotoreceptor matrix. Here the outer limiting membrane was within $20 \mu \mathrm{m}$ of Bruch's membrane, and, unlike situations where disease results in loss of photoreceptor cells, there was no proliferation of glial elements external to the outer limiting membrane. Extensive villus-like processes from the outer- 
Table 1 Comparison of the clinical features of the Kearns-Sayre and Laurence-Moon-Biedl syndromes

\begin{tabular}{|c|c|c|c|c|}
\hline & $K-S$ & Case I & $L-M-B$ & Case 2 \\
\hline \multicolumn{5}{|l|}{ Eye features } \\
\hline \multicolumn{2}{|l|}{ Poor visual acuity } & $6 / 36$ & Common & $6 / 36$ \\
\hline and/or night vision & $40 \%$ & No & Common & Yes \\
\hline \multicolumn{5}{|l|}{ Ptosis and/or external } \\
\hline ophthalmoplegia & $100 \%$ & Yes & Reported & No \\
\hline Nystagmus & Not reported & No & Common & Yes \\
\hline Corneal opacitics & $5-11 \%$ & No & Not reported & No \\
\hline Cataracts & Reported & Yes & Reported & Yes \\
\hline Pale discs & Reported (rare) & No & Reported & Yes \\
\hline Attenuated vessels & Reported (rare) & No & Reported & Yes \\
\hline Maculopathy & Reported (rare) & No & Reported & No \\
\hline Abnormal retinal pigment & $100 \%$ & Yes & $79 \%$ & Yes \\
\hline Abnormal ERG & Common & Normal & Common & Flat \\
\hline Abnormal VER & Common & Normal & Common & Not done \\
\hline Impaired intellect & $32-64 \%$ & No & $87 \%$ & Yes \\
\hline Seizure disorder & Reported(rare) & Yes & Reported (rare) & No \\
\hline Auditory dysfunction & $47-79 \%$ & Yes & Reported & No \\
\hline Vestibular dysfunction & $77-85 \%$ & Not assessed & Not reported & No \\
\hline Muscle: weakness & $63-80 \%$ & Yes & Reported (rare) & No \\
\hline Wasting & Reported & Yes & Reported (rare) & No \\
\hline Abnormal reflexes & decreased $(40 \%)$ & Decreased & Reported (rare) & Normal \\
\hline Abnormal tone & Reported (hypo) & Normal & Reported (rare) & Normal \\
\hline Cerebellar dysfunction & $63-69 \%$ & Marked & Reported (rare) & Mild \\
\hline Abnormal EEG & Common & Yes & Common & Not done \\
\hline CT scan (atrophy) & Reported & Yes & Not reported & Not done \\
\hline Spongy degeneration (CNS) & Reported & Not reported & Not reported & No \\
\hline \multicolumn{5}{|l|}{ General features } \\
\hline Failure to thrive & Common & Marked & Not reported & No \\
\hline Obesity & Not reported & No & $91 \%$ & No \\
\hline Short stature & $78 \%$ & Yes & Reported (rare) & No \\
\hline Polydactyly & Not reported & No & $73 \%$ & Yes \\
\hline Cardiac conduction defect & $84-100 \%$ & Yes & Not reported & No \\
\hline Cardiomyopathy & Reported & Yes & Reported (rare) & No \\
\hline Confenital heart disease & Not reported & No & Common & No \\
\hline Chronic renal failure & Reported & Yes & Common & Yes \\
\hline Genitourinary anomaly & Reported & Yes & $74 \%$ & Yes \\
\hline \multicolumn{5}{|l|}{ Laboratory investigations } \\
\hline Ragged-red fibres & Common & Yes & Not reported & Not done \\
\hline Abnormal mitochondria (EM) & Common & No EM & Not reported & Not done \\
\hline Elevated CSF protein & $74-100 \%$ & Yes & Not reported & Not done \\
\hline Elevated pyruvate/lactate & Common & Not done & Not reported & Not done \\
\hline Elevated CK & Common & Yes & Not reported & Not done \\
\hline Anacmia & Reported & Yes & Reported & Yes \\
\hline Scrum amino acids & $(+\mathrm{A} 1 \mathrm{a})$ reported & Not done & $\begin{array}{l}\text { (+ branched chain and } \\
\text { arg.) reported }\end{array}$ & Not done \\
\hline Amino aciduria & Not reported & $(+)$ ala. & Not reported & $(+)$ gly. \\
\hline Hypoparathyroidism & $12 \%$ & Yes & Not reported & No \\
\hline Elevated blood glucose & Reported & Yes & Reported (rare) & No \\
\hline
\end{tabular}

most aspects of Müller's fibres were prominent only where photoreceptor cell outer segments were present.

Cone remnants in the central retina displayed a remarkably similar ultrastructure, showing a reduction in the ellipsoid mitochondrial content and a dissolution of the myoid region of the inner segment, with a commensurate loss of Golgi bodies and lysosomes. In most cells in this region there were polymorphic autophagic vacuoles. Both the inner and outer connecting fibres of these residual cones were easy to identify because of the simplicity of the outer nuclear layer resulting from atrophy of a significant number of cells. Remaining synaptic pedicles in the outer plexiform layer were enlarged, but were simplified with reduced synaptic contacts.

In the mid peripheral zone short disorganised outer segments were related to both rods and cones, 
and their discs were misaligned with membranes at right angles to their normal axis, often fused to form vesiculate and tubular arrays. As these very short and disorganised outer segments terminated in the extracellular membrane sheets at the apical surface of the RPE, it was difficult to discriminate between interand intracellular membrane systems, and their length could not be measured. The length of the outer segments increased with their distance from the macula. Mid peripheral cone inner segments showed similar changes to those in the central region with reduced numbers of organelles but with more autophagic vacuoles.

\section{Discussion}

The diagnosis of mitochondrial cytopathy in the first case study was made by using Kearns and Sayre's ${ }^{3}$ original criteria and those of subsequent studies. ${ }^{582021}$

Fundal changes in mitochondrial cytopathy range from fine granular salt-and-pepper pigmentation to a 'moth-eaten' appearance, though they are sometimes described as 'atypical retinitis pigmentosa.' The defects leading to this retinal degeneration are unknown. However, abnormal mitochondria have been found in biopsies of various other tissues and occur most frequently in skeletal muscle, but have also been observed in liver, ' cerebellum, ${ }^{22}$, heart ${ }^{23}$ skin, ${ }^{21}$ and smooth muscle. ${ }^{24}$ Histochemistry also shows a mitochondrial defect by demonstating altered mitochondrial enzyme activity, ${ }^{8}$ with a decrease in cytochrome oxidase activity and an increase in that of succinate dehydrogenase. ${ }^{256}$

There are 10 reports on ocular histopathology; two papers report the same cases. Therefore the total data are five histological reports and three accounts of - ultrastructure. ${ }^{327-34}$ The consistent histological picture is of marked atrophy and degeneration of the outer retinal layers and RPE but preservation of the ganglion cell and nerve fibre layers. Our case 1 conforms to this morphological pattern with generalised loss of the outer retina and preservation of the inner retinal layers. The loss of vessels in the choriocapillaris in our young patient was significant, and like Sarks ${ }^{35}$ we believe that as retinal cells die the choriocapillaris atrophies secondarily to reduced metabolic demand. The mitochondria in the preserved areas of the inner segment were shrunken, with atypical electron dense membranes and abnormal arrays of cristae.

Given the ambiguities in the clinical diagnosis of mitochondrial cytopathy, the range of presenting symptoms, and the age range of the small number of patients with ocular histological studies, the variation between the cases is not surprising. Histopathology is a spatial analysis of temporal processes, and the superimposition of one spectrum (time) on a second spectrum (genetic variability) complicates direct comparison. Some useful generalisations can be made. Characteristically abnormal mitochondria are not found in ocular tissues. Mitochondria from nonocular tissues in mitochondrial cytopathies are misshapen, with concentric cristae or paracrystalline inclusions, ${ }^{53-12}$ and they are so frequent in the skeletal muscles that they may give rise to the 'ragged red fibres' seen on microscopy. Ragged red fibres were present in skeletal muscles of our patient but not in extraocular muscle. These abnormal organelles and the multisystem degenerations in these inherited disorders suggest that the genetic defects are primarily expressed in aberrant mitochondrial function. ${ }^{37}$ All inherited diseases are phenotypically expressed in aberrant biochemistry. In the mitochondrial cytopathies, if the biochemical lesions are present in all mitochondria, then their actions must proceed at different rates in different sites, but everywhere they must be at least normal enough for survival. In the inherited dystrophies the genetic lesions show during early life and perhaps reflect the progressive failure of repair mechanisms of aging.

Mitochondria have been examined in retinal tissues, but changes similar to those described systemically have not been identified, though enlarged mitochondria within the retinal pigment epithelium have been described ${ }^{314}$; these authors concede that the changes may be due to post-mortem autolysis. In a study of a 14-year-old patient with the Kearns-Sayre syndrome large numbers of enlarged mitochondria within the retinal pigment epithelium were implicated in photoreceptor cell $\operatorname{loss}^{34}$ by their disturbing the energy relationships required for homoeostasis of visual cells. ${ }^{44}$ The argument here is that mitochondrial proliferation is a compensation for reduction in efficiency, which in turn results in changes in dependent cells. Such a causal relationship is uncertain, but from the morphological evidence in both the McKechnie report ${ }^{34}$ and our study it could equally be argued that the mitochondrial changes are secondary to failure of transepithelial transport with reduced exchange area, that is, the loss of convolutions on the basal membrane of the remaining pigment epithelial cells.

Whatever the primary mechanism, we support McKechnie et al. ${ }^{34}$ and Eagle et al.,$^{31}$ who consider that the genetic defect is first expressed in the RPE and that photoreceptor cell losses are secondary. Our conclusions are based on these related observations.

(1) Photoreceptor cells were absent where RPE cells were absent.

(2) The shape of photoreceptor cell remnants closely followed the degree of atrophic changes within adjacent RPE cells. 
(3) There was very little invasion of RPE cells into the neural retina in the 'bone spicule zone.'

(4) There was significant loss of choroidal capillaries in areas of RPE cell loss.

The role of the RPE in photoreceptor cell maintenance means that a malfunction in any one of a number of interrelated processes could result in photoreceptor cell death. ${ }^{+4}$ Animal studies show that in some inherited retinal dystrophies the defective gene action is expressed solely within the RPE cells. ${ }^{456}$ In our study the RPE lesions have sharply defined edges, while the overlying photoreceptor cells have more graded changes. The large amounts of unphagocytosed subretinal lipids near residual photoreceptors indicate a malfunction in the underlying RPE cells. Both aspects of photoreceptor damage distribution suggest a primary malfunction within the pigment cells, with a secondary involvement of dependent cells, a phenomenon suspected in gyrate atrophy ${ }^{47}$ This concept is further supported by the lack of pigmented cells in the neural retina. Where photoreceptor cells are lost in the presence of RPE cells the latter become migratory. Atrophy of RPE cells results in windows enabling the choroid to be seen ophthalmoscopically. The depletion of RPE with the absence of pigmented cells in the neural retina results in the 'salt-and-pepper' fundus. The loss of choroidal capillaries is usually in conditions in which severe changes occur in the RPE rather than in the photoreceptor cells. ${ }^{35}$

The diagnosis of the Laurence-Moon-Biedl syndrome in the second case was made on the basis of the retinal dystrophy, postaxial polydactyly, and mild mental retardation. Two of the five cardinal features of the Laurence-Moon-Biedl syndrome, obesity and hypogenitalism, were absent, but obesity and hypogenitalism are often difficult to diagnose in early childhood. ${ }^{910489}$ Our patient's mother strictly controlled his diet, thereby limiting his weight.

Chronic renal failure was the presenting feature, and the strong family history of renal disease is therefore of interest (Fig. 2). Several members of our patient's family, although asymptomatic, were found to have unilateral duplex kidneys when investigated by ultrasound. There is increasing evidence that renal and genitourinary tract anomalies are much more common in this syndrome than previously recognised. " 12 SLLSS The majority of necropsies of the Laurence-Moon-Biedl syndrome report a genitourinary tract abnormality, and in one series uraemia was the commonest cause of death. "19

Patients with the Laurence-Moon-Biedl syndrome commonly present with nystagmus, failing vision, and night blindness. ${ }^{9}$ The ERG is always abnormal. Funduscopy may be normal early in the disease, but a retinal degeneration almost always develops, ${ }^{5 s}$ being present in $93 \%$ of cases. '" 'Typical' retinitis pigmentosa is found in only 15 to $20 \%$ of cases, ${ }^{56}$ while in the majority pigmentary changes are 'atypical.' Various morphologies, described as a diffuse pigmentary retinopathy, retinitis pigmentosa sine pigmento, retinitis punctata albescens, other forms of tapetoretinal degeneration, and pigmentary retinopathy of undetermined type together with choroidal and macular degenerations, have been observed. This heterogeneity may be due either to a spectrum of disease within the syndrome or to describing patients at different points of development in the disease.

Most reports of ocular histopathology have been on patients over 18 years of age. ${ }^{56-61}$ Usually they are described as having advanced retinal degeneration with loss of rods, cones, and outer and inner nuclear layers, reduction of the ganglion cell layer with glial proliferation and degeneration, and proliferation of the RPE. Most of the eyes had little or no vision and must be regarded as being at the end stage of a retinal degeneration. When McLoughlin and Shanklin ${ }^{62}$ examined their two patients with the LaurenceMoon-Biedl syndrome they found no abnormalities grossly or histologically. Their patients were three months and five years of age respectively and therefore may not have had time to develop the pigmentary retinopathy.

In contrast to case 1 , the histopathology of the outer retina in case 2 showed photoreceptor cell degeneration without significant changes in the RPE. The underlying mechanisms are as obscure as the reason for the distribution of the lesions with severest degeneration at the macula. The disease in this eye affected photoreceptor cells selectively, without discrimination between rods or cones. The macular changes probably reflect a complex regional differentiation rather than the selective loss of cone cells.

The lipofuscin and other granular inclusions within the RPE cells indicate one or more of the following:

(1) these cells have had a prolonged phagocytic load; (2) they have had an excessive load recently; (3) the RPE cells had a problem in lysing and voiding an ingested phagocytic load.

In conditions (1) and (2) a normal pigment epithelium is implicit, and in condition (3) the problems in the RPE could be secondary to biochemical anomalies within the outer segments, rendering them indigestible.

That there was relatively normal RPE throughout the eye, and that there were areas where the overlying photoreceptor cells were normal, degenerate, or non-existent, strengthens our conclusions that in this case the primary problem was in the photoreceptor cells. This was supported by experiments on the phagocytic behaviour of RPE cells from this patient grown in tissue culture. ${ }^{17}$ In these, human 
RPE cells were challenged with rod outer segments from cattle, and the number of particles engulfed per cell in cultures of our case 2 were statistically indistinguishable from the numbers engulfed by cells derived from normal human eyes. If this dynamic analysis of the phagocytic activity of these cells is a true representation of their in vivo capacity, then the extracellular accumulation of photoreceptor cell membranes in the mid peripheral retina must be an indication that these membranes are in some way undesirable or deficient in their ability to initiate phagocytosis.

Because of the complexity of the interactions between the photoreceptor cells and the RPE there is great potential for defects in a number of processes and at different cellular locations in giving rise to photoreceptor cell decay. ${ }^{44}$ While we cannot identify the exact site or biochemical defect underlying the degenerative changes in either of our cases, we believe that these two patients are examples of inherited retinal dystrophies in which the defective gene expression occurs in different cell populations.

We gratefully acknowledge the financial assistance of the American Retinitis Pigmentosa Foundation, the British Retinitis Pigmentosa Society, and the Wellcome Trust. We thank the following colleagues: Professor T M Barrett, Professor C Chantler, Dr George Haycock, Dr Ann Harden, Dr Brian Lake, and Dr J Pincott, and we are indebted to $\mathrm{Mr}$ Bill Parmar and Mr Stephen Rothery for technical assistance and Mrs Vera Borrow, Corinne White, and Miss Josephine Lace for preparing the manuscript.

\section{References}

1 Gonatas NK. A generalised disorder of the nervous system, skeletal muscle and heart resembling Refsum's disease and Hurler's syndrome. II. Ultrastructure. Am J Med 1967; 42: 169-78.

2 Tassin S, Brucher JM. The mitochondrial disorders; pathogenesis and aetiological classification. Neuropathol Appl Neurobiol 1982; 8: 251-63.

3 Kearns TP, Sayre GP. Retinitis pigmentosa, external ophthalmoplegia and complete heart block. Unusual syndrome with histological study in one of two cases. Arch Ophthalmol 1958; 60: 280-9.

4 Drachman DA. Ophthalmoplegia plus. The neurodegenerative disorders associated with progressive external ophthalmoplegia. Arch Neurol 1968; 18: 654-74.

5 Berenberg RA, Pellock JM, DiMauro S, et al. Lumping or splitting? 'Ophthalmoplegia-plus' or Kearns-Sayre syndrome? Ann Neurol 1977; 1: 37-54.

6 Rheuban KS, Ayres NA, Sellers TD, DiMarco JP. Near-fatal Kearns-Sayre syndrome. A case report and review of clinical manifestations. Clin Pediatr 1983; 22: 822-5.

7 Butler IJ, Gadoth N. Kearns-Sayre syndrome. A review of a multisystem disorder of children and young adults. Arch Intern Med 1976; 136: 1290-3.

8 Egger J, Lake BD, Wilson J. Mitochondrial cytopathy. A multisystem disorder with ragged red fibres on muscle biopsy. Arch Dis Child 1981; 56: 741-52.

9 Bell J. The Laurence-Moon syndrome. In: Enrose LS, ed. The treasury of human inheritance. London: Cambridge University Press, 1958: 5: 51-69.
10 Prosperi L, Cordella M, Bernasconi S. Electroretinography and diagnosis of the Laurence-Moon-Bardet-Biedl syndrome in childhood. J Pediatr Ophthalmol 1977; 14: 305-8.

11 Nadjmi B, Flanagan MJ, Christian JR. Laurence-Moon-Biedl syndrome associated with multiple genitourinary tract anomalies. Am J Dis Child 1969; 117: 352-6.

12 Hurley RM, Dery P, Nogrady MB, Drummond KN. The renal lesion of the Laurence-Moon-Biedl syndrome. J Pediatr 1975; 87: 206-9.

13 Belman AB, Kaplan GW. Genital abnormalities in the male. In: Schaffer AJ, Markowitz M, eds. Major problems in clinical pediatrics. Genitourinary Problems in Pediatrics. Philadelphia: Saunders, 1981: 23: 160-98.

14 Kelly DG, Hyland J. The evaluation of intravenous pyelography in undescended testis. In: Bergsma D, Duckett JW, eds. Birth Defects. Urinary system malformations in children. New York: Liss, 1977; 13: 287-91.

15 Rubenstein M, Meyer R, Bernstein J. Congenital abnormalities of the urinary system. I. A postmortem survey of the developmental anomalies and acquired congenital lesions in a children's hospital. J Pediatr 1961; 58: 356-66.

16 Boulton ME, Marshall J, Mellerio J. Retinitis pigmentosa: a preliminary report on tissue culture studies of retinal pigment epithelial cells from eight affected human eyes. Exp Eye Res 1983; 37: 307-13.

17 Boulton M, Marshall J, Mellerio J. Retinitis pigmentosa: a quantitative study- of the apical membrane of normal and dystrophic human retinal pigment epithelial cells in tissue culture in relation to phagocytosis. Graefes Arch Klin Exp Ophthalmol 1984; 221 : 214-29.

18 Boulton ME, Marshall J, Mellerio J. An analysis of some behavioural characteristics of normal and dystrophic human RPE cells in tissue culture. Ophthalmic Paediatr Genet in press.

19 Dowling JE, Sidman RL. Inherited retinal dystrophy in the rat. J Cell Biol 1962; 14: 73-109.

20 Karparti G. The Kearns-Sayre-Shy syndrome. In: Vinken PJ, Bruyn GW, eds. The handbook of clinical neurology. Amsterdam: North-Holland, 1979; 38: 211-32.

21 Karpati G, Carpenter S, Larbrisseau A, Lafontaine R. The Kearns-Shy syndrome. A multisystem disease with mitochondrial abnormality demonstrated in skeletal muscle and skin. J Neurol Sci 1973; 19: 133-51.

22 Schneck L, Adachi M, Briet P, Wolintz A, Volk BW. Ophthalmoplegia plus with morphological and chemical studies of cerebellar and muscle tissuc. J Neurol Sci 1973; 19: 37-44.

23 Bastiaensen LAK, Joosten EMG, de Rooij JAM, et al. Ophthalmoplegia-plus, a real nosological entity. Acta Neurol Scand 1978; 58: 9-34.

24 Pellock JM, Berenberg R, DiMauro S, et al. Kearns-Sayre syndrome or ophthalmoplegia-plus? To lump or to split? Trans Am Neurol Assoc 1976; 101: 133-7.

25 Lake BD, Smith VV, Stevenson B. A cytochrome oxidase defect in miotochondrial cytopathy. In: Abstracts of the VIIth International Congress of Histochemistry and Cytochemistry. Helsinki, 5-11 August 1984: 216.

26 Clark JB, Hayes DJ, Morgan-Hughes JA, Byrne E. Mitochondrial myopathies: disorders of the respiratory chain and oxidative phosphorylation. J Inherit Dis 1984; 7 (suppl 1): 62-8.

27 Jager BV, Fred HL, Butler RB, Carnes WH. Occurrence of retinal pigmentation, ophthalmoplegia, ataxia, deafness and heart block. Report of a case with findings at autopsy. Am J Med 1960; 29: 888-93.

28 Kearns TP. External ophthalmoplegia, pigmentary degeneration of the retina and cardiomyopathy: a newly recognized syndrome. Trans Am Ophthalmol Soc 1965; 63: 559-625.

29 Daroff RB, Solitare GB, Pincus JH, Glaser GH. Spongiform encephalopathy with chronic progressive external ophthalmoplegia. Central ophthalmoplegia mimicking ocular myopathy. Neurology 1966; 16: 161-9. 
30 Horwitz SJ, Roessmann U. Kearns-Sayre syndrome with hypoparathyroidism. Ann Neurol 1978; 3: 513-8.

31 Eagle RC Jr, Hedges TR, Yanoff M. The atypical pigmentary retinopathy of Kearns-Sayre syndrome. A light and electron microscopic study. Ophthalmology (Rochester) 1982; 89: 1433-40.

32 Eagle RC Jr, Hedges TR, Yanoff M. The Kearns-Sayre syndrome: a light and electron miscoscopic study. Trans Am Ophthalmol Soc 1982; 80: 218-34.

33 Egger J, Wynne-Williams CJE, Erdohazi M. Mitochondrial cytopathy of Leigh's syndrome? Mitochondrial abnormalities in spongiform encephalopathies. Neuropediatrics 1982; 13: 219-24.

34 McKenchnie NM, King M, Lee WR. Retinal pathology in the Kearns-Sayre syndrome. Br J Ophthalmol 1985; 69: 63-75.

35 Sarks SH. Aging and degeneration in the macular region: a clinicopathological study. Br J Ophthalmol 1976; 60: 324-41.

36 Leveille AS, Newell FW. Autosomal dominant Kearns-Sayre syndrome. Ophthalmology (Rochester) 1980; 87: 99-108.

37 Bossen EH. Muscular disorders. In: Garner A, Klintworth GK, eds. Pathobiology of ocular disease: New York: Dekker, 1982: 1603-44.

38 Rieske-Nielsen E, Lon HC, Lowes M. Progressive external ophthalmoplegia. Evidence for a generalized mitochondrial disease with a defect in pyruvate metabolism. Acta Ophthalmol (Kbh) 1975; 54: 553-73.

39 Hyman BN, Patten BM, Dodson RF. Mitochondrial abnormalities in progressive external ophthalmoplegia. Am J Ophthalmol 1977; 8: 362-71.

40 Rimgel SP, Wilson WB, Barden MT. Extraocular muscle biopsy in chronic progressive external ophthalmoplegia. Ann Neurol 1979; 6: 326-39.

41 Eshaghian J, Anderson RL, Weingiest TA, Hart MN, Cancilla PA. Orbicularis oculi muscle in chronic progressive external ophthalmoplegia. Arch Ophthalmol 1980; 98: 1070-3.

42 Zintz R, Villiger W. Elektronenmikroskopische befunde bei 3 fallen von chronisch progressiver okularer Muskeldytrophie. Ophthalmologica 1967; 153: 439-59.

43 Newell FW, Palascik HA. Mitochondrial disease and retinal pigmentary degeneration. In: Schimiza $\mathrm{K}$, Oosterhuis $\mathbf{J}$, eds. Proceedings of the 23rd International Congress of Ophthalmology, Kyoto 1978. Amsterdam: Excerpta Medica International Congress Series 450, 1979: 615-7.

44 Bird AC, Marshall J. Retinal receptor disorders without known metabolic abnormalities. In: Garner $A$, Klintworth $G$, eds. Pathobiology of ocular disease. New York: Dekker, 1982: 1167-220.

45 Lavail MM, Mullen RJ. Experimental chimeras: a new approach to the study of inherited retinal degeneration in laboratory animals. Adv Exp Med Biol 1977; 77: 153-73.

46 Mullen R, Lavail M. Iṇherited retinal dystrophy: primary defect in pigment epithelium determined with experimental rat chimeras. Science 1976; 192: 799-801.

47 Takki K. Gyrate atrophy of the choroid and retina associated with hyperornithinaemia. Br J Ophthalmol 1974; 58: 3-23.

48 Ehrenfeld EN, Rowe H, Auerbach E. Laurence-Moon-BardetBiedl syndrome in Israel. Am J Ophthalmol 1970; 70: 524-32.

49 Bauman ML, Hogan GR. Laurence-Moon-Biedl syndrome. Am J Dis Child 1973; 126: 119-26.

50 Landau J, Bromberg YM, Schorr J. Laurence-Moon-Biedl syndrome with multiple congenital malformations of the urinary tract. Acta Med Oriental 1949; 8: 205-10.

51 Alton DJ, McDonald P. Urographic findings in the Bardet-Biedl syndrome, formerly the Laurence-Moon-Biedl syndrome. Radiology 1973; 109: 659-63.

52 Falkner B, Langman C, Katz S. Renal histopathological changes in a child with Laurence-Moon-Biedl syndrome. J Clin Pathol 1977; 30: 1077-81.

53 Bluett NH, Chantler C, Singer JD, Saxton HM. Congenital renal abnormalities in the Laurence-Moon-Biedl syndrome. Arch Dis Child 1977; 52: 968-79.

54 Srinivas V, Winsor GM, Dow D. Urologic manifestations of the Laurence-Moon-Biedl syndrome. Urology 1983; 21: 581-3.

55 Lyle DJ. Early ocular manifestations in the Laurence-MoonBiedl syndrome. Am J Ophthalmol 1946; 29; 939-46.

56 Klein D, Ammann F. The syndrome of Laurence-Moon-BardetBiedl and allied diseases in Switzerland. Clinical, genetic and epidemiological studies. J Neurol Sci 1969; 9: 479-513.

57 Brattgard S. The pathology of Laurence-Moon-Bield syndrome. Acta Pathol Scand 1949; 26: 525-37.

58 Bisland T. The Laurence-Moon-Biedl syndrome. Report of a typical case with complete necropsy. Am J Ophthalmol 1951; 34: 875-84.

59 Ross CF, Crome L, Mackenzie DY. The Laurence-Moon-Biedl syndrome. J Pathol Bacteriol 1956; 72: 161-72.

60 Stanescu B, Nereantu F. Laurence-Moon-Bardet-Biedl syndrome with juvenile macular degenerescence Stargardt. Clinical and pathological study. Ophthalmologica 1971; 162: 76-81.

61 Lahav M, Albert DM, Buyukmihci N, et al. Ocular changes in Laurence-Moon-Bardet-Biedl syndrome: a clinical and histopathologic study of a case. Adv Exp Med Biol 1977; 77: 51-84.

62 McLoughlin TG, Shanklin DR. Pathology of the LaurenceMoon-Bardet-Biedl syndrome. J Pathol Bacteriol 1967; 93: 65-79.

Accepted for publication 2 January 1986. 